\title{
PERTUMBUHAN LALAT BUAH (Drosopilla Sp.) PADA BERBAGAI MEDIA DAN SUMBANGANNYA PADA PEMBELAJARAN BIOLOGI DI SMA
}

\author{
Eko Sri Wahyuni \\ Program Studi Pendidikan Biologi FKIP Universitas Tanjungpura \\ Pontianak, Indonesia \\ ekosri_w83@yahoo.co.id
}

\begin{abstract}
ABSTRAK
Penelitian ini bertujuan untuk mendapatkan informasi tentang media terbaik untuk perkembangan lalat buah (Drosophila sp.). Lalat buah yang digunakan adalah F1 virgin, media yang digunakan adalah campuran buah pepaya, pisang, nanas, semangka, mangga dan agar-agar. Parameter yang diamati meliputi jumlah telur, jumlah imago, panjang tubuh dan lebar tubuh lalat buah jantan dan betina. Penelitian ini manggunakan metode eksperimen dan Rancangan Acak Lengkap (RAL) yang terdiri atas 5 perlakukan dan 4 ulangan. P1 (pepaya+agar-agar), P2 (pisang+agar-agar), P3 (nanas+agar-agar), P4 (semangka+agar-agar) dan P5 (mangga+agar-agar). Data yang diperoleh dianalisis dengan uji F dilanjutkan dengan BJND. Hasil penelitian menunjukkkan bahwa perbedaan media berpengaruh nyata terhadap semua parameter kecuali pada parameter panjang tubuh jantan. Media terbaik yang dapat digunakan sebagai media alternatif adalah pada perlakuan P2. Hasil penelitian ini diharapakan dapat dijadikan materi pengayaan pada pelajaran Biologi di SMA kelas X semester I pada kompetensi dasar siswa mampu mendeskripsikan dan mengkomunikasikan ciri-ciri invertebrata dan peranannya bagi kehidupan. Materi pokok animalia dan uraian materi invertebrata (insekta).
\end{abstract}

Kata kunci : perkembangan, media, Drosophila sp.

\section{Pendahuluan}

Lalat buah nerupakan hewan percobaan yang sering digunakan dalam praktikum genetika. Beberapa hukum genetika yang penting telah dihasilkan dari penelitian menggunakan lalat buah (Strickberger, 1985). Beberapa keunggulan penggunaan lalat buah antara lain tidak memerlukan kondisi steril seperti pada mikroorganisme, mudah diperoleh karena bersifat kosmopolit, siklus hidup pendek, mudah dipelihara, lalat betina bertelur banyak, cirri morfologi mudah diamati dan memiliki 4 pasang kromosom sehingga mudah diteliti (Iskandar, 1987).

Ada dua faktor yang mempengaruhi perkembangan serangga. Pertama, faktor dalam yang meliputi kemampuan berkembang biak, perbandingan jenis kelamin, sifat mempertahankan diri dan siklus hidup. Faktor kedua yaitu, faktor luar yang meliputi suhu, kelembaban, cahaya, pakan atau nutrisi serta predator (Jumar, 2001). Lalat buah termasuk dalam ordo dipteral yang mengalami metamorphosis sempurna (holometabola) dengan empat stadium perkembangan yaitu telur - larva - pupa - imago. Telur-telur lalat buah diletakkan oleh betina dewasa dalam jaringan buah(Kartasaputra,1987).

Lalat buah biasa dijumpai pada medium pisang, papaya, tomat, nasi basi dan tempat sampah disekitar rumah (Yatim, 1991). Lebih lanjut, Shorrocks (1972) dalam Rivaida (1996) menyatakan, lalat buah mendatangi buah-buahan yang ranum disebabkan karena adanya zat fermentasi yang memiliki aroma kuat sehingga mereka tertarik dan datang pada buah-buahan tersebut. Lalat buah lebih menyukai buah yang masak karena mengandung zat-zat yang mereka butuhkan. Selain itu, makanan, akan mempengaruhi jumlah telur lalat betina dan perkembangan larvanya. Larva dan imago lalat 
buah makan substansi kaya karbohidrat yang mengalami fermentasi (Iskandar, 1987).

Dalam praktikum genetika, media standar yang digunakan untuk pemeliharaan lalt buah adalah media pisang+tape, dengan perbandingan 6:1, 6 bagin pisang dan 1 bagian tape. Kandungan utama dalam buah-buahan adalah karbohidrat, yang merupakan bagian dari zat gizi utama yang berperan sebagai sumber energi.

Penelitian ini bertujuan untuk mengetahui perkembangan lalat buah dan memperoleh informasi tentang media terbaik untuk perkembangan lalat buah.

\section{Metode Penelitian}

Penelitian ini dilaksanakan pada bulan Januari-Februari 2005 di Jln. Kopral Urip No.4 Plaju-Palembang. Alat dan bahan yang digunakan adalah botol selai, gelas sloki kecil, kertas saring, mikroskop, kaca objek, kaca penutup, gelas ukur, kuas kecil, kain kasa, , pipet tetes, thermometer ruangan, hygrometer, pisau, baki, kertas millimeter, karet, sendok, saringan, timbangan, lup, blender, cawan petri, kertas label, mistar, alat tulis. Bahan yang digunakan meliputi: pisang ambon, papaya, mangga arumanis, nanas, agar-agar, tape singkong, alcohol $70 \%$, eter, lalat buah yang ditangkap di plaju.

Parameter yang diamati meliputi jumlah telur, jumlah imago, panjang tubuh dan lebar tubuh lalat buah jantan dan betina. Penelitian ini manggunakan metode eksperimen dan Rancangan Acak Lengkap (RAL) yang terdiri atas 5 perlakukan dan 4 ulangan. P1 (pepaya+agar-agar), P2 (pisang+agar-agar), P3 (nanas+agar-agar), P4 (semangka+agar-agar) dan P5 (mangga+agar-agar). Data yang diperoleh dianalisis dengan uji $\mathrm{F}$ dilanjutkan dengan BJND.

Cara kerja dalam penelitian ini meliputi persiapan tempat pemeliharaan lalat buah, persiapan lalat buah uji, persiapan media, pemeliharaan lalat buah, pengamatan dan pengambilan data dan pengukuran suhu dan kelembaban.

\section{Hasil Penelitian}

Tabel 1. Rata-Rata Hasil Pengukuran Parameter Lalat Buah

\begin{tabular}{|l|l|l|l|l|l|l|}
\hline P & JT & JI & PTB & PTJ & LTB & LTJ \\
\hline P1 & 2,47 & 2,14 & 2,76 & 2,23 & 0,95 & 0,76 \\
\hline P2 & 2.63 & 2,39 & 2,84 & 2,18 & 1,03 & 0,848 \\
\hline P3 & 2,49 & 2,16 & 2,8 & 2,12 & 1,015 & 0,852 \\
\hline P4 & 2,52 & 2,23 & 2,77 & 2,16 & 1,018 & 0,84 \\
\hline P5 & 2,59 & 2,33 & 2,79 & 2,2 & 1,01 & 0,83 \\
\hline
\end{tabular}

Ket: JT: jumlah telur, JI: jumlah imago, PTB: panjang tubuh betina, PTJ: panjang tubuh jantan, LTB: lebar tubuh betina, LTJ: lebar tubuh jantan.

Berdasarkan tabel 1. Nilai tertinggi untuk parameter jumlah telur, jumlah imago, panjang tubuh betina, dan lebar tubuh betina terdapat pada P2. Sedangkan nilai terendah untuk jumlah telur dan jumlah imago terdapat pada P1 dan P3. Angka-angka yang terdapat pada kolom jumlah telur dan jumlah imago sebelumnya ditransformasikan dulu dalam bentuk logaritma. P3 menunjukkan perbedaan kurang bermakna dengan P2 dan P4 pada parameter lebar tubuh jantan. Kisaran suhu pada penelitian ini antara $27-30^{\circ} \mathrm{C}$ dan kisaran kelembaban 78-92,6\%.

Tabel 2. Rekapitulasi Hasil ANAVA terhadap Parameter Perkembangan Drosophila

\begin{tabular}{|c|c|c|c|c|}
\hline \multirow{2}{*}{ No } & \multirow{2}{*}{ Parameter } & \multirow{2}{*}{$\begin{array}{c}\mathrm{F} \\
\text { Hitung }\end{array}$} & \multicolumn{2}{|c|}{ F Tabel } \\
\hline & & & 0,05 & 0,01 \\
\hline 1 & Jumlah telur (butir) & $3,4 *$ & \multirow{6}{*}{3,06} & \multirow{6}{*}{4,89} \\
\hline 2 & Jumlah imago (ekor) & $6,1^{*}$ & & \\
\hline 3 & $\begin{array}{l}\text { Pjg tubuh betina } \\
(\mathrm{mm})\end{array}$ & $13,33 * *$ & & \\
\hline 4 & $\begin{array}{l}\text { Pjg tubuh jantan } \\
(\mathrm{mm})\end{array}$ & 0,049 & & \\
\hline 5 & $\begin{array}{l}\text { Lebar tubuh betina } \\
(\mathrm{mm})\end{array}$ & $3,3 *$ & & \\
\hline 6 & $\begin{array}{l}\text { Lebar tubuh jantan } \\
(\mathrm{mm})\end{array}$ & $6,88^{*}$ & & \\
\hline
\end{tabular}

Berdasarkan tabel 2, untuk parameter panjang tubuh jantan menunjukkan hasil yang tidak berbeda nyata. Sedangkan untuk parameter lainnya menunjukkan hasil yang berbeda nyata 
dan berbeda sangat nyata. Selanjutnya parameter yang berbeda nyata diuji lanjut dengan uji BJND.

1Berdasarkan hasil uji Duncan untuk parameter jumlah telur, P2 berbeda nyata dengan P1 dan P3, untuk parameter jumlah imago P2 berbeda sangat nyata terhadap P3 dan P4. Sedangkan P5 berbeda nyata terhadap P1 dan P3. Hasil uji Duncan untuk panjang tubuh betina P2 berbeda sangat nyata dengan P1, P4 P5 sedangakan P3 berbeda nyata terhadap P1 dan P4. Dan P5 berbeda nyata terhadap P1. Selanjutnya untuk parameter lebar tubuh betina, P2 berbeda sangat nyata terhadap P1, sedangkan P4, P3, dan P5 berbeda nyata terhadap P1. Untuk parameter lebar tubuh jantan, semua perlakuan berbeda sangat nyata terhadap P1.

\section{Pembahasan}

Berdasarkan hasil penelitian lalat buah (Drosophila sp.) yang diberi perlakuan dengan P2 (pisang+agar-agar) dan P5 (mangga+agaragar) untuk parameter jumlah telur dan jumlah imago nilainya lebih besar dibanding dengan lalat buah pada perlakuan P1 (pepaya+agaragar), P3 (nanas+agar-agar), dan P4 (semangka+agar-agar). Berdasarkan hasil uji lanjut untuk parameter jumlah telur, terlihat bahwa P2 berbeda nyata terhadap P1 dan P3, sedangkan P5 berbeda nyata terhadap P1. Begitu juga uji lanjut untuk jumlah imago. Hal ini disebabkan oleh kandungan karbohidrat yang cukup tinggi pada pisang dan mangga. Kandungan karbohidrat pada pisang adalah 28,5 gram per 100 gram buah pisang yang dapat dimakan atau daging buahnya (Santoso, 1995), sedangkan kandungan karbohidrat pada 100 gram mangga adalah 16-18 gram (Afriansyah, 2004).

Di alam bebas larva dan lalat buah dewasa memakan substansi kaya karbohidrat yang mengalami fermentasi (Iskandar, 1987).
Karbohidrat memegang peranan penting dalam dalam pertumbuhan Drosophila karena karbohidrat merupakan komponen utama dalam buah-buahan dan merupakan bagian dari zat gizi utama penghasil energi. Menurut Campbell, dkk (2002) karbohidrat dapat digolongkan menjadi tiga yaitu: monosakarida, disakarida, dan polisakarida. Pati atau amilum merupak polisakarida yang dihasilkan dari proses fotosintesis dan banyak terdapat pada buahbuahan (Piliang dan Djoyosubagio, 1996).

Kandungan protein dan lemak sangat rendah dalam buah-buahan. Seperti yang kita ketahui bahwa zat yang diperlukan dalam pertumbuhan adalah protein, sedangkan dalam buah-buahan kandungan protein sangat rendah, dengan demikian Drosophila memerlukan protein yang diubah dari karbohidrat untuk pertumbuhannya.

Karbohidrat dapat diubah menjadi
protein melalui proses yang disebut transaminasi. Poedjiadi (1994) menyatakan bahwa transaminasi merupakan proses katabolisme asam amino yang melibatkan pemindahan gugus amino dari satu asam amino ke asam amino yang lain. Dalam reaksi transaminasi ini gugus amino dari suatu asam amino dipindahkan kepada salah satu dari tiga senyawa keto, yaitu asam piruvat, asam alpha ketoglutarat dan asam oksaloasetat, sehingga senyawa ini diubah menjadi asam amino, sedangkan asam amino semula diubah menjadi asam keto dengan bantuan enzim. Asam piruvat, oksaloasetat, dan alpha ketoglutarat (senyawa yang terbentuk dari oksidasi glukosa) dapat diubah dengan cara transaminasi menjadi Lalanina, asam L-aspartat, dan asam L-Glutamat. Asam glutamat dan asam aspartat merupakan pra zat sejumlah besar asam amino (Robinson, 1991).

Dari lima pasang lalat buah jantan dan betina pada setiap perlakuan, rata-rata jumlah 
telur terbanyak adalah 435 butir pada P2 selama 12 hari pengamatan. Menurut Strickberger (1962), setelah berumur kira-kira satu minggu, Drosophila melanogaster betina dapat menghasilkan 50-75 butir telur perhari dan maksimum dapat menghasilkan 400-500 telur selama 10 hari. Kemampuan bertelur Drosophila pada penelitian ini lebih rendah karena jenis spesies dalam penelitian ini bukan merupakan Drosophila melanogaster, karena menurut Iskandar (1987), Drosophila melanogaster sangat jarang ditemukan di indonesia. Disamping bukan merupakan spesies Drosophila melanogaster, suhu dan kelembaban juga berpengaruh pada jumlah telur lalat buah.

P2 menunjukkan nilai yang lebih besar untuk parameter panjang tubuh betina dan lebar tubuh betina, sedangkan nilai terendah terdapat pada P1. Selain itu, lalat buah Drosophila betina memiliki tubuh yang relatif lebih panjang dan lebih lebar dibandingkan dengan lalat buah Drosophila jantan. Hal ini berhubungan dengan keperluan kopulasi dan bertelur pada lalat buah betina (Borror, 1992). Pada betina terdapat ovarium yang ukurannya sangat bervariasi tergantung pada perkembangan telur dan dipengaruhi oleh faktor makanan dari induknya.Jika ovarium besar menyebabkan abdomen lalat buah betina kelihatan menggelembung, sehingga tampak jauh lebih besar dari pada jantan (Shorrocks, 1972 dalam Junitha dkk, 1993).

Jadi, keaktifan induk makan pada media yang baik akan menentukan kualitas dan jumlah telur, sehingga menghasilkan larva yang sehat dan aktif makan dan bergerak. Larva yang sehat akan menjadi pupa yang sehat pula dan akhirnya menghasilkan jumlah imago yang lebih banyak dan sehat.

Hasil penelitian ini diharapkan dapat dijadikan sebagai materi pengayaan pada pelajaran Biologi di SMA kelas X semester I pada kompetensi dasar mendeskripsikan dan mengkomunikasikan ciri-ciri invertebrata dan peranannya bagi kehidupan. Untuk mencapai kompetensi dasar, diberikan contoh perangkat pembelajaran kurikulum berbasis kompetensi yaitu silabus dan sistem penilaian, rencana pembelajaran, pedoman untuk guru, panduan tugas di rumah, wacana hasil penelitian, lembar kegiatan siswa (LKS). Metode pembelajaran dilaksanakan dengan metode diskusi informasi dan pendekatan inkuiri. Pendekatan inkuiri merupakan suatu rangkaian kegiatan belajar yang melibatkan secara maksimal seluruh kemampuan siswa untuk mencari dan menyelidiki secara sistematis, logis, kritis, analisis, sehingga mereka dapat merumuskan sendiri penemuannya dengan penuh percaya diri (Gulo, 2002)

\section{Kesimpulan dan Rekomendasi}

Media terbaik dalam penelitian ini adalah pisang+agar-agar. Saran pada penelitian ini adalah perlu dilakukan penelitian tentang pengaruh media menggunakan spesies Drosophila tertentu.

\section{Daftar Pustaka}

Afriansyah, N. 2004. Menu Mangga. Diakses 10 Oktober 2004 dari www.terranet.or.id/goto berita.php?id.

Borror, J., Triplehorn dan Jhonson, F. 1992. Pengenalan Pelajaran Serangga. Penerjemah: Soetiyono,P. Yogyakarta: UGM Press

Campbell, Reece, Mitchell. 2002. Biologi. Edisi kelima Jilid I. Penerjemah: Rahayu Lestari. Jakarta: Aneka Ilmu.

Gulo. W. 2002. Strategi Belajar Mengajar. Jakarta: Grasindo

Iskandar, D.T. 1987. Petunjuk Praktikum Genetika. Bandung: ITB 
Jumar. 2000. Entomologi Pertanian. Jakarta: Rineka Cipta

Kartasaputra. 1987. Hama Hasil Tanaman Dalam Gudang. Jakarta: Bina Aksara.

Piliang,W.G dan Djoyosubagio,S. 1996. Fisiologi Nutrisi Volume I. Jakarta: UI Press

Poedjiadi, A. 1994. Dasar-Dasar Biokimia. Jakarta: UI

Rivaida, I. 1996. Inventarisasi Spesies Lalat Buah Genus Drosophila di Kotamadya Palembang. Skripsi S1 FMIPA. Inderalaya: Unsri.

Robinson, T. 1991. Kandungan Organik Tumbuhan Tinggi. Bandung: ITB

Santoso, H.B. Saus Pisang. 1995. Yogyakarta. Kanisius

Strickberger,M.W. 1962. Experiment in Genetics With Drosophila. New York: John Wiley and Sons, Inc

Strickberger,M.W. 1985. Genetics. New York: Macmillan Publishing Company.

Yatim, W. 1991. Genetika. Bandung: Tarsito 